\title{
Ammonia Desorption Peaks Can Be Assigned to Different Copper Sites in Cu/SSZ-13
}

\author{
Kirsten Leistner $^{1} \cdot$ Kunpeng Xie $^{1} \cdot$ Ashok Kumar $^{2} \cdot$ Krishna Kamasamudram $^{2}$. \\ Louise Olsson ${ }^{1}$
}

Received: 23 January 2017 / Accepted: 15 May 2017 / Published online: 7 June 2017

(C) The Author(s) 2017. This article is an open access publication

\begin{abstract}
The purpose of this study is to attribute $\mathrm{NH}_{3}$-TPD peaks observed over $\mathrm{Cu} / \mathrm{SSZ}-13$ catalysts to different catalytic sites. This is done by comparing a large number of copper loadings, especially below $40 \%$ ion exchange, to be able to see effects relevant to sites in both 6-membered and 8-membered rings. We found that intermediate $\left(200-300^{\circ} \mathrm{C}\right)$ and high $\left(400-500^{\circ} \mathrm{C}\right)$ temperature $\mathrm{NH}_{3}$-TPD peaks followed similar trends to the copper species in 6-membered and 8-membered rings respectively, as seen by $\mathrm{H}_{2}$-TPR and NO-DRIFTS. Thus we propose that these two TPD peaks represent ammonia stored on $\mathrm{H}$ and $\mathrm{Cu}$ sites in 6 and 8-membered rings, respectively. This assignment is further supported by the finding that the intermediate and high temperature $\mathrm{NH}_{3}$-TPD peaks of samples with different $\mathrm{Si} / \mathrm{Al}$ ratios also follow the same trend. Moreover, we observe that the activation energy for ammonia oxidation is significantly lower for $\mathrm{Cu}$ in $6 \mathrm{MR}$ compared to $\mathrm{Cu}$ in $8 \mathrm{MR}$ rings.
\end{abstract}

Electronic supplementary material The online version of this article (doi:10.1007/s10562-017-2083-8) contains supplementary material, which is available to authorized users.

Louise Olsson

louise.olsson@chalmers.se

1 Competence Centre for Catalysis, Chemical Engineering, Chalmers University of Technology, 41296 Gothenburg, Sweden

2 Cummins Inc., 1900 McKinley Ave, MC 50183, Columbus, IN 47201, USA

\section{Graphical Abstract}

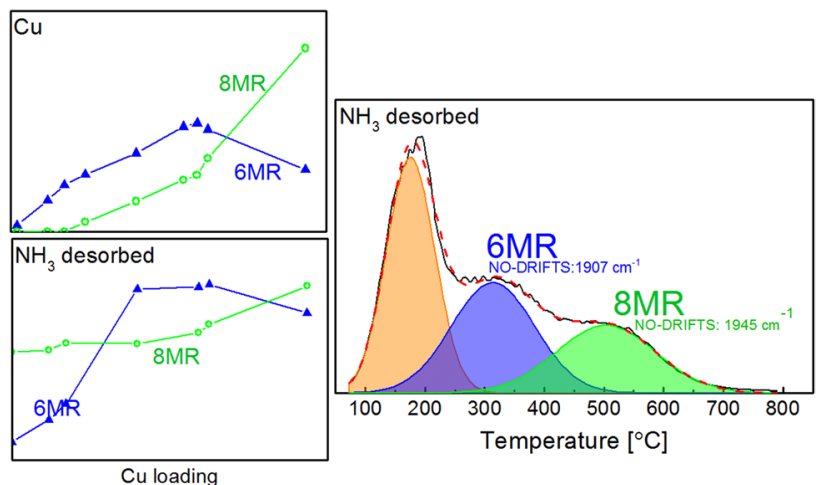

Keywords Copper loading $\cdot \mathrm{Cu} / \mathrm{SSZ}-13 \cdot \mathrm{NH}_{3}$ adsorption $\cdot$ Chabazite $\cdot$ Six-membered rings $\cdot$ Large cages $\cdot \mathrm{Si} / \mathrm{Al}$ ratio

\section{Introduction}

In the current framework of increasingly stringent $\mathrm{NO}_{\mathrm{x}}$ emission regulations, the continuous improvement of $\mathrm{NO}_{\mathrm{x}}$ removal technologies is critical. Such improvement is largely made possible by the development of increasingly efficient catalysts, for instance for the ammonia selective catalytic reduction $\left(\mathrm{NH}_{3}\right.$-SCR) reaction in lean-burn engine exhausts. Most recently, small-pore materials such as the zeolite $\mathrm{Cu} / \mathrm{SSZ}-13$ have become popular for ammonia SCR as a result of their excellent hydrothermal stability compared to the more established medium-pore zeolites [1].

Ammonia storage is an important step of selective catalytic reduction over $\mathrm{Cu}$ /zeolites. Ammonia-TPD is also used as a method of characterising the acid sites in the zeolite. Nevertheless, it can be challenging to unequivocally 
assign peaks observed during TPD. In the case of $\mathrm{Cu}$ / SSZ-13, two peaks are typically seen at $\sim 250-350$ and $\sim 450-500^{\circ} \mathrm{C}$. There is no consensus as to the assignment of these: the former has been attributed to ammonia stored either on $\mathrm{Cu}^{2+}$ sites [2,3] or both Brønsted and Lewis acid sites [4] and the latter to either Brønsted acid sites [2, 4, 5] or copper sites [3]. It has been shown that $\mathrm{Cu} / \mathrm{SSZ}-13$ can contain copper sites in two different locations: the 6-membered rings (6MR) and chabazite cages (8-membered rings or $8 \mathrm{MR}$ ) [6]. It is also known that the 6MRs are populated by $\mathrm{Cu}$ sites at low copper loadings, whereas the $8 \mathrm{MRs}$ are occupied only at higher copper loadings [6]. However, the connection between the TPD peaks and these two different $\mathrm{Cu}$ site location has not been extensively studied. Moreover, while there are two published studies using different copper loadings as a tool to understand the TPD peaks [2, 3, 7], neither correlated ammonia storage with different positions in the zeolite. This could be because Lezcano-Gonzalez et al. [2] used only two $\mathrm{Cu}$-loadings (ion exchange levels $(\mathrm{IE})=67$ and $100 \%$ ) and Clemens et al. [3] used only one sample below 20\% IE. Yet, it is clear that low copper loadings are critical in order to assign the ammonia TPD peaks, given that Kwak et al. found that a sample with $\mathrm{IE}=20 \%$ already contains $\mathrm{Cu}$ sites in both 6MRs and 8MRs [6].

However, to our knowledge, there are no studies available that assign the ammonia desorption peaks to ammonia adsorbed in different positions in the zeolite based on experimental findings, which is the objective of this study. In more detail, the goal of this study is thus to use a large number of $\mathrm{Cu} / \mathrm{SSZ}-13$ samples with loadings above and below 20\% IE to interpret the ammonia-TPD peaks and correlate them with sites in different locations in the zeolite. Another factor that we take into consideration to make the assignment of the TPD peaks easier, is the presence of $\mathrm{CuO}$ species. In this study, we use liquid ion exchange, which is known to produce fewer $\mathrm{CuO}$ species in $\mathrm{Cu} / \mathrm{SSZ}$ 13 compared to solid ion exchange. In addition we aim to assign DRIFT peaks to the different sites and use Cu/SSZ13 samples with different $\mathrm{Si} / \mathrm{Al}$ ratios to further support the assignment of $\mathrm{Cu}$ sites to specific positions.

\section{Experimental}

\subsection{Catalyst Preparation}

The SSZ-13 used for this study was synthesised using the same procedure as in an earlier study [8]. First, $320 \mathrm{~g}$ of MilliQ water and $250 \mathrm{~g}$ of sodium silicate solution (Sigma-Aldrich, 338443-1L) were added to $200 \mathrm{~mL}$ $\mathrm{NaOH}$ solution $(1 \mathrm{M}$, prepared using anhydrous pellets from Sigma-Aldrich, >98\%) and the mixture was stirred for $15 \mathrm{~min}$. Thereafter, $25 \mathrm{~g}$ of Y-zeolite were added spoon-wise and then the mixture was stirred for $30 \mathrm{~min}$. This was followed by addition of $105 \mathrm{~g}$ of TMAAI solution (25\% solution, Sachem, ZeoGen SDA 2825) and the mixture was stirred for another $30 \mathrm{~min}$. Finally, the mixture was transferred into a $2 \mathrm{~L}$ stirred autoclave, heated to $140^{\circ} \mathrm{C}$ and left to stir at this temperature for 6 days. Thereafter, the solid fraction was separated from the liquid by vacuum filtration, rinsed thoroughly and dried at room temperature. The obtained powder was calcined for $8 \mathrm{~h}$ at $550^{\circ} \mathrm{C}$, with a heating rate of $0.5^{\circ} \mathrm{C} / \mathrm{min}$ and then ground in an agate mortar. Note that the samples with different $\mathrm{Si} / \mathrm{Al}$ ratios were obtained by using Y-zeolite CBV300, CBV712, CBV720 (Zeolyst International), for $\mathrm{Si} / \mathrm{Al}=3.7,6.0$ and 9.6, respectively.

The obtained Na-SSZ-13 was exchanged twice with a $2 \mathrm{M}$ solution of $\mathrm{NH}_{4} \mathrm{NO}_{3}$ at $80^{\circ} \mathrm{C}$ for $15 \mathrm{~h}(30 \mathrm{~g}$ zeolite per $1 \mathrm{~L} \mathrm{NH}_{4} \mathrm{NO}_{3}$ ). Then the catalyst was ion-exchanged with a solution of $\mathrm{Cu}\left(\mathrm{NO}_{3}\right)_{2}$, using $100 \mathrm{~mL}$ of solution per gram of zeolite. All exchanges were carried out at $80^{\circ} \mathrm{C}$ for $60 \mathrm{~min}$, rinsing with MiliQ water after each exchange. Finally, the powders were dried and calcined at $550^{\circ} \mathrm{C}$ for $4 \mathrm{~h}\left(5^{\circ} \mathrm{C} / \mathrm{min}\right.$ ramp $)$. Note that one sample of H/SSZ-13 was produced by calcination of the $\mathrm{NH}_{4} / \mathrm{SSZ}$ 13 form. To obtain different copper loadings, molarity of the $\mathrm{Cu}\left(\mathrm{NO}_{3}\right)_{2}$ solution, $\mathrm{Cu}\left(\mathrm{NO}_{3}\right)_{2}$ /zeolite ratio and number of exchanges were varied, as in Table 1.

\subsection{Catalyst Characterisation}

Inductively coupled plasma sector field mass spectrometry (ICP-SFMS) was used to determine the elemental composition of the catalysts (carried out by ALS Scandinavia AB). The catalysts were further

Table $1 \mathrm{Cu} / \mathrm{SSZ}-13$ catalysts with different $\mathrm{Cu}$ loadings $(\mathrm{Si} / \mathrm{Al}=3.7)$ and respective copper ion exchange conditions

\begin{tabular}{llllll}
\hline $\begin{array}{l}\mathrm{Cu} \\
\text { loading } \\
(\mathrm{wt} \%)\end{array}$ & $\begin{array}{l}\text { IE\% } \\
\text { exchanges }^{\mathrm{a}}\end{array}$ & $\begin{array}{l}\text { Nolarity of } \\
\mathrm{Cu}\left(\mathrm{NO}_{3}\right)_{2} \\
\text { solution }\end{array}$ & $\begin{array}{l}\mathrm{Cu}\left(\mathrm{NO}_{3}\right)_{2} / \\
\text { zeolite } \\
(\mathrm{mL} / \mathrm{g})\end{array}$ & $\mathrm{BET}\left(\mathrm{m}^{2} / \mathrm{g}\right)$ \\
\hline 0 & 0 & 0 & n.a & n.a & 408 \\
0.17 & 2 & 1 & $6.80 \times 10^{-4}$ & 33 & 369 \\
0.94 & 9 & 1 & $4.50 \times 10^{-3}$ & 33 & 399 \\
1.37 & 15 & 1 & $9.00 \times 10^{-3}$ & 33 & 416 \\
1.90 & 19 & 1 & $22.5 \times 10^{-3}$ & 33 & 436 \\
3.18 & 36 & 1 & $2.00 \times 10^{-1}$ & 33 & 415 \\
4.39 & 47 & 2 & $2.00 \times 10^{-1}$ & 33 & 396 \\
4.73 & 53 & 3 & $2.50 \times 10^{-2}$ & 100 & 395 \\
5.00 & 56 & 3 & $2.00 \times 10^{-1}$ & 33 & 394 \\
7.48 & 73 & 1 & $2.00 \times 10^{-1}$ & 33 & n.d \\
\hline
\end{tabular}

n. $a$ Not applicable, $n . d$ not determined

${ }^{a}$ Number of exchanges with copper nitrate 
characterised using $\mathrm{N}_{2}$ adsorption, UV-Vis spectroscopy, $\mathrm{H}_{2}$-temperature programmed reduction $\left(\mathrm{H}_{2}\right.$-TPR), NO-diffuse reflectance infrared fourier transform spectroscopy (NO-DRIFTS) and $\mathrm{NH}_{3}$ adsorption-desorption $\left(\mathrm{NH}_{3}\right.$-TPD). Nitrogen adsorption-desorption at $77 \mathrm{~K}$ for Brunauer-Emmett-Teller (BET) measurements and t-plot pore volume measurements was performed using a Tristar 3000 (Micromeritics) instrument. Prior to the measurement, the samples were outgassed under vacuum at $220^{\circ} \mathrm{C}$ for $4 \mathrm{~h}$. UV-Vis spectroscopy was carried out using a Carry 5000 UV-Vis NIR spectrophotometer in diffuse reflectance mode. All samples were heat-treated at $550^{\circ} \mathrm{C} 24 \mathrm{~h}$ prior to acquisition of the UV-Vis spectra. While the samples are thus not entirely dehydrated, they are in a similar condition, and comparison between them should be possible.

DRIFTS measurements were performed using a Bruker 70 FTIR spectrometer and Harrick Praying Mantis DR accessory. Approximately $70 \mathrm{mg}$ of catalyst powder was placed on a porous grid in the sample cup. The sample was covered by a dome equipped with two $\mathrm{KBr}$ windows, and reactant gases were flown through the sample using Bronkhorst mass flow controllers. Each sample was pretreated for $45 \mathrm{~min}$ in $8 \% \mathrm{O}_{2}$ at $500^{\circ} \mathrm{C}$ and then cooled down to $30^{\circ} \mathrm{C}$. At this temperature a background was first acquired under Ar flow, and then the flow was switched to $500 \mathrm{ppm}$ NO for $60 \mathrm{~min}$. During this time, a spectrum was acquired every $60 \mathrm{~s}$ using a scanner velocity of of $20 \mathrm{kHz}$ and a resolution of $4 \mathrm{~cm}^{-1}$.

TPR, TPD and ammonia oxidation experiments were carried out in a powder reactor. Approximately $60 \mathrm{mg}$ of catalyst powder was placed on a porous quartz frit in the sample tube. Feed flowrate was $20 \mathrm{~mL} / \mathrm{min}$ for both types of experiment. Catalysts were degreened for $3 \mathrm{~h}$ in $400 \mathrm{ppm} \mathrm{NO}$ and $8 \% \mathrm{O}_{2}$ prior to both TPR and TPD experiments. Prior to each measurement, the surface of the catalyst was cleaned by exposing it to $8 \% \mathrm{O}_{2}$ at $500^{\circ} \mathrm{C}$ for $1 \mathrm{~h}$. A Hiden HPR-20 QUI mass spectrometer (MS) was used to measure the $\mathrm{H}_{2}$ and $\mathrm{NH}_{3}$ mole fractions at the exit of the catalyst-containing tube. TPR was performed from 50 to $800^{\circ} \mathrm{C}$ with a heating rate of $10^{\circ} \mathrm{C} /$ min and with $0.3 \% \mathrm{H}_{2}$ in Ar. The tube was cooled down to $50{ }^{\circ} \mathrm{C}$ and $0.3 \%$ of $\mathrm{H}_{2}$ were introduced into the flow and the temperature kept at $50{ }^{\circ} \mathrm{C}$ for $45 \mathrm{~min}$. Thereafter the temperature was raised to $800^{\circ} \mathrm{C}$ at a ramping rate of $10^{\circ} \mathrm{C} / \mathrm{min}$ and then kept at $800^{\circ} \mathrm{C}$ for a further $60 \mathrm{~min}$. The $\mathrm{NH}_{3}$-TPD experiments consisted of an adsorption phase of $5 \mathrm{~h}$ at $70^{\circ} \mathrm{C}$ during which $2000 \mathrm{ppm}$ of $\mathrm{NH}_{3}$ were flown through the bed, followed by a purge in $\mathrm{Ar}$ at $70^{\circ} \mathrm{C}$ and a temperature ramp of $10^{\circ} \mathrm{C} / \mathrm{min}$. Finally, ammonia oxidation experiments were also carried out in the same powder reactor. The total flow rate for these experiments was $100 \mathrm{~mL} / \mathrm{min}$, and a catalyst bed of mass
$35 \mathrm{mg}$ and particle size $180-250 \mu \mathrm{m}$ was used. Prior to each experiment, the catalyst was degreened as described above and then pre-treated in $8 \% \mathrm{O}_{2}$ at $500^{\circ} \mathrm{C}$ for $30 \mathrm{~min}$. Ammonia oxidation was carried out with 1200 ppm $\mathrm{NH}_{3}$ and $8 \% \mathrm{O}_{2}$. The outlet ammonia concentration was measured using the MS and steady state ammonia concentrations at each temperature were used to calculate ammonia conversions.

\section{Results and Discussion}

In Sect. 3.1 to 3.4, the results from samples with different copper loadings will be discussed. In Sect. 3.5, site positioning assignments are made based on these results, and additional results from the samples with different $\mathrm{Si} / \mathrm{Al}$ ratios will be presented to further support these assignments.

\subsection{Elemental Composition}

The elemental composition of the catalysts was determined by ICP-SFMS. Ten samples with different copper loadings were synthesised. The obtained copper loadings for these samples were comprised between 0.17 and 7.48 wt $\%$ and are shown in Table 1. The average Si/Al ratio for the samples was 3.7 and the ion exchange levels, determined as $\mathrm{IE} \%=2 \cdot \mathrm{Cu} / \mathrm{Al} \cdot 100 \%$, are between 2 and $73 \%$. BET areas are also shown in Table 1 . Three Cu/SSZ-13 samples with different $\mathrm{Si} / \mathrm{Al}$ ratios were also synthesised, and their copper contents as determined by ICP-SFMS are shown in Table 2. Note that the copper contents of these three samples are different, but IE\% levels are reasonably similar.

\subsection{UV-Vis Spectroscopy and $\mathrm{H}_{2}$-TPR}

The electronic transitions of the copper ions in the zeolite were probed by UV-Vis diffuse reflectance (DR) spectroscopy and the results shown in Fig. 1. The large

Table $2 \mathrm{Cu} / \mathrm{SSZ}-13$ catalysts with different $\mathrm{Si} / \mathrm{Al}$ ratios and respective copper ion exchange conditions

\begin{tabular}{llllll}
\hline $\mathrm{Si} / \mathrm{Al}$ & $\begin{array}{l}\mathrm{Cu} \\
\text { loading } \\
(\mathrm{wt} \%)\end{array}$ & $\mathrm{IE} \%$ & $\begin{array}{l}\text { No. of } \\
\text { exchanges }\end{array}$ & $\begin{array}{l}\text { Molarity of } \\
\mathrm{Cu}\left(\mathrm{NO}_{3}\right)_{2} \text { solu- } \\
\text { tion }\end{array}$ & $\begin{array}{l}\mathrm{Cu}\left(\mathrm{NO}_{3}\right)_{2} / \\
\text { zeolite } \\
(\mathrm{mL} / \mathrm{g})\end{array}$ \\
\hline 3.7 & 5.50 & 65 & 3 & $2.00 \times 10^{-1}$ & 33 \\
6.0 & 4.22 & 66 & 3 & $2.00 \times 10^{-1}$ & 33 \\
9.6 & 3.20 & 72 & 3 & $2.00 \times 10^{-1}$ & 33 \\
\hline
\end{tabular}




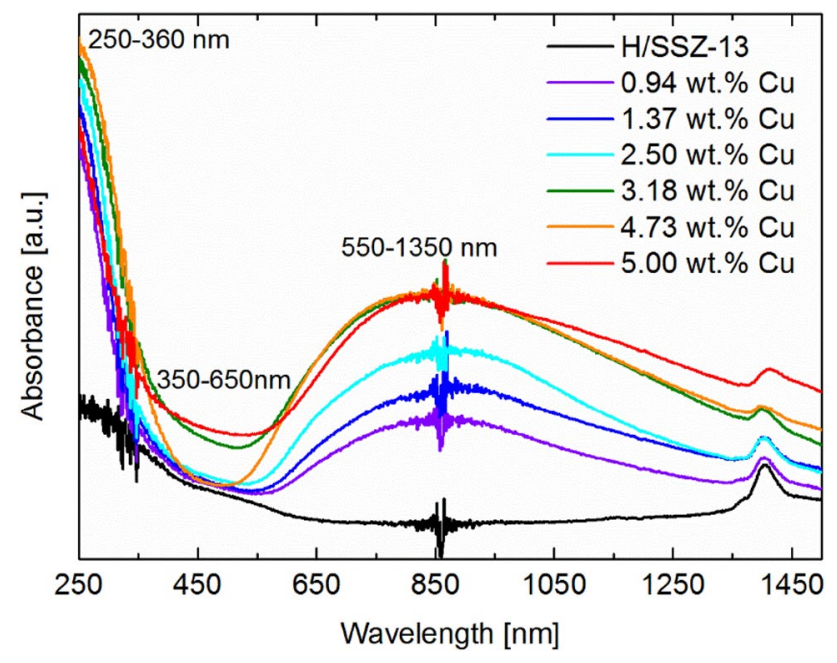

Fig. 1 UV-Vis DR spectra of H/SSZ-13 and Cu/SSZ-13 catalysts $(\mathrm{Si} / \mathrm{Al}=3.7)$

feature between approx. 250 and $360 \mathrm{~nm}$ includes, amongst others, the contributions of $\mathrm{O}^{2-} \rightarrow \mathrm{Cu}^{2+}$ chargetransfer transitions and $\mathrm{d} 10-\mathrm{d} 9 \mathrm{~s} 1$ transitions of $\mathrm{Cu}^{+1}$ [3], as well as transitions characteristic of the copper-free zeolite H/SSZ-13. Between 550 and $1350 \mathrm{~nm}$, another broad band is observed, which is characteristic of the copper sites, because it is not observed in the spectrum of H/SSZ-13 and has been assigned to the $\mathrm{d}-\mathrm{d}$ transitions of isolated $\mathrm{Cu}^{2+}$ [9-12] or copper hydroxyl species [13]. Bands in the range 350 and $650 \mathrm{~nm}$ are typically assigned to transitions in oxidic copper species, such as charge transfer transitions in $\mathrm{O}-\mathrm{Cu}-\mathrm{O}$ and $\mathrm{Cu}-\mathrm{O}-\mathrm{Cu}$ and $\mathrm{Cu}^{+}$ in $3 \mathrm{~d}$ clusters in $\mathrm{CuO}[3,12,14]$. While care should be taken in making quantitative interpretations of UV-Vis DR spectra, the general trend observed in Fig. 1 indicates few oxidic copper species in the samples with low copper loadings. Slightly increased amounts of oxidic copper are seen for the higher copper loadings, particularly 3.18 and $5.00 \mathrm{wt} \% \mathrm{Cu}$.

$\mathrm{H}_{2}$-TPR was performed to further characterise the copper sites, see Fig. 2a. Integration of the peaks obtained between 100 and $700{ }^{\circ} \mathrm{C}$ yields $\mathrm{H}_{2} / \mathrm{Cu}$ ratios near 0.5 for all the samples except the lowest $\mathrm{Cu}$ loadings (Table 3), indicating a one-electron reduction, most likely from $\mathrm{Cu}^{2+}$ to $\mathrm{Cu}^{+}$, given the oxidative pre-treatment. The higher values for low loadings are due to the significant measurement noise on the MS signal.

All samples show a main reduction peak centered around $430{ }^{\circ} \mathrm{C}$ (Peak 1) and some also have a shoulder at $300{ }^{\circ} \mathrm{C}$ (Peak 2). This shoulder appears only for the samples with a higher copper loading. This behaviour has previously been observed by Kwak et al. [6], who attributed the peak at $430^{\circ} \mathrm{C}$ and the lower-temperature shoulder to
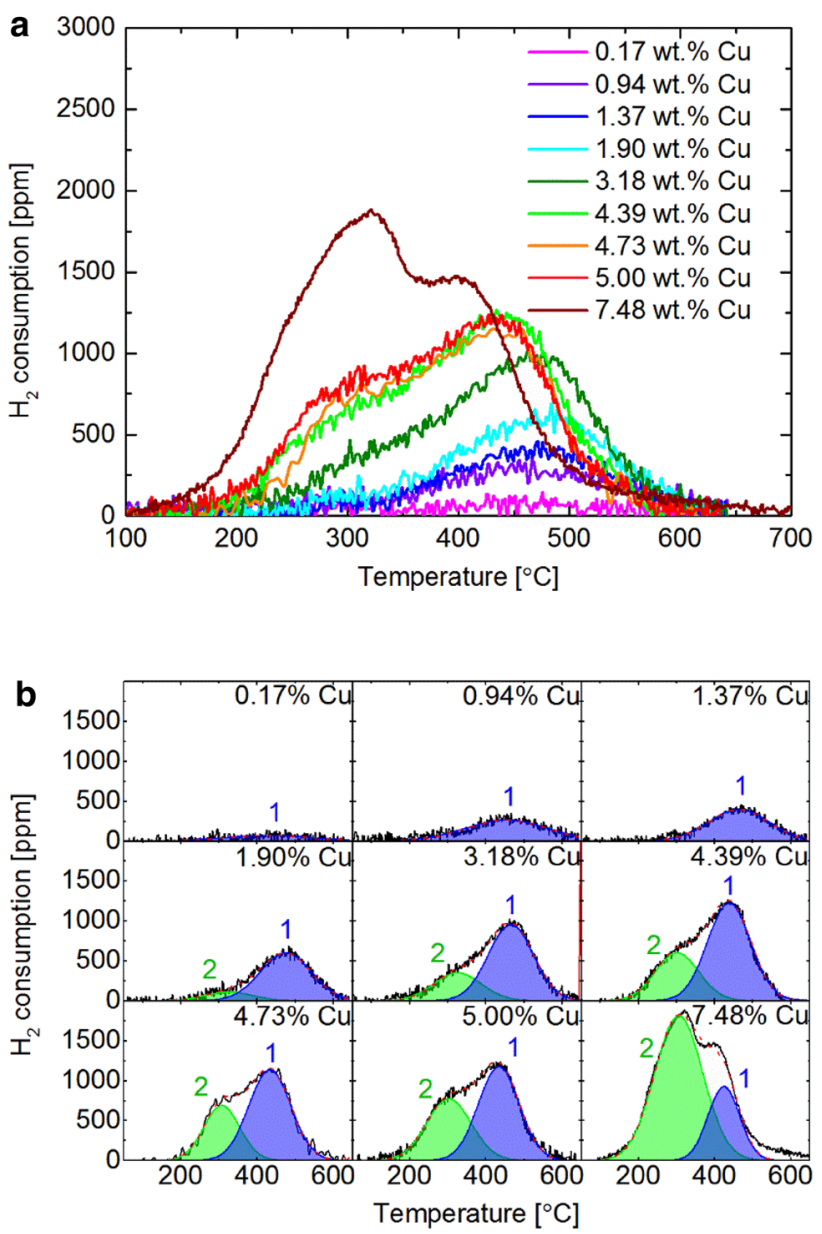

Fig. $2 \mathrm{H}_{2}$-TPR of $\mathrm{Cu} / \mathrm{SSZ}-13$ catalysts $(60 \mathrm{mg}$ catalyst, $\mathrm{Si} / \mathrm{Al}=3.7$, flow rate $20 \mathrm{~mL} / \mathrm{min}, 3000 \mathrm{ppm} \mathrm{H}_{2}$, heating rate $10^{\circ} \mathrm{C} / \mathrm{min}$ ). a $\mathrm{H}_{2}$ consumption profiles during $\mathrm{H}_{2}$-TPR. b Deconvoluted $\mathrm{H}_{2}$ consumption profiles during $\mathrm{H}_{2}$-TPR

copper sites located in the 6MR units, and the 8MR units, respectively. From this observation, the authors deduced that the 6MRs are filled with copper first, and the 8MRs are only filled later, at higher copper loadings. Our observations agree with the results by Kwak et al. In addition,

Table $3 \mathrm{H}_{2} / \mathrm{Cu}$ ratio for $\mathrm{H}_{2-}$ TPR of $\mathrm{Cu} / \mathrm{SSZ}-13$ catalysts between 100 and $700^{\circ} \mathrm{C}$

\begin{tabular}{ll}
\hline $\mathrm{Cu}$ wt\% & $\mathrm{H}_{2} / \mathrm{Cu}$ \\
\hline 7.48 & 0.52 \\
5.00 & 0.51 \\
4.73 & 0.48 \\
4.39 & 0.55 \\
3.18 & 0.60 \\
1.90 & 0.58 \\
1.37 & 0.56 \\
0.94 & 0.77 \\
0.17 & n.d \\
\hline n.d not determined &
\end{tabular}


we observe a new shoulder between 200 and $300{ }^{\circ} \mathrm{C}$ on the sample with the highest copper loading, $7.48 \mathrm{wt} \% \mathrm{Cu}$. This is possibly evidence that a third type of copper species may be forming at these high copper contents. Since copper oxide species are known to appear on zeolites with high copper loadings, it is reasonable to suppose that this shoulder is connected with such species. This interpretation is also consistent with the reduction temperature of copper oxides, $230{ }^{\circ} \mathrm{C}$ [7].

In order to extract the contribution of the different types of copper sites, the TPR profiles were deconvoluted by fitting with two Gaussian curves as shown in Fig. 2b. All profiles were fitted using two peaks, although the appearance of the new shoulder in $7.48 \mathrm{wt} \% \mathrm{Cu}$ indicates that a third peak could be fitted. This choice was based on the fact that it would be difficult to obtain a meaningful fit with a third peak: given that it is just a slight shoulder, many different fits are conceivable. We thus preferred
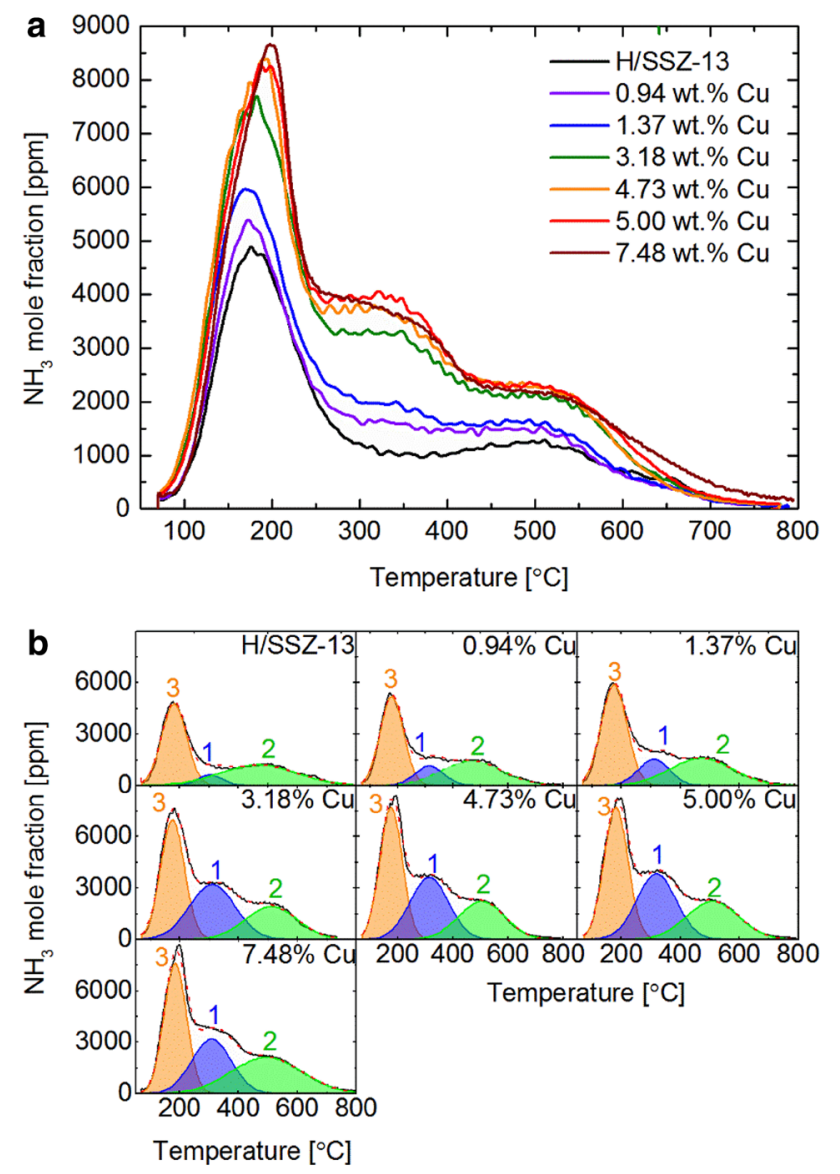

Fig. $3 \mathrm{NH}_{3}$-TPD profiles of $\mathrm{Cu} / \mathrm{SSZ}-13$ catalysts $(\mathrm{Si} / \mathrm{Al}=3.7)$ after $\mathrm{NH}_{3}$ adsorption and Ar purge over $\mathrm{Cu}(\mathrm{H}) / \mathrm{SSZ}-13$ at $70^{\circ} \mathrm{C}$. Adsorption time: $5 \mathrm{~h}$, purge time: $1 \mathrm{~h}$. Heating rate: $10^{\circ} \mathrm{C} / \mathrm{min}$, flow rate $20 \mathrm{~mL} / \mathrm{min}, 2000 \mathrm{ppm} \mathrm{NH}_{3}$. Catalyst mass: $60 \mathrm{mg}$. a $\mathrm{NH}_{3}$-TPD profiles after $\mathrm{NH}_{3}$ adsorption and Ar purge. b Deconvoluted $\mathrm{NH}_{3}$-TPD profiles after $\mathrm{NH}_{3}$ adsorption and Ar purge to interpret the results based on a fitting with only two peaks.

\subsection{Ammonia-TPD}

Figure $3 \mathrm{a}$ shows the desorption profiles of ammonia stored at $70{ }^{\circ} \mathrm{C}$ on SSZ-13 samples with different copper loadings. All samples show the presence of three desorption peaks, centered at $175-198^{\circ} \mathrm{C}$ (low temperature, Peak 3), $238-319^{\circ} \mathrm{C}$ (intermediate temperature, Peak 1) and $463-512^{\circ} \mathrm{C}$ (high temperature, Peak 2) respectively. The general trend of all three peaks appears to be increasing height with increasing copper loading. Peak 3 at $175-198^{\circ} \mathrm{C}$ can probably be assigned to desorption of loosely bound ammonia not removed during the purge step $[2,4,5]$. Assignment of the other two peaks is more complex. Earlier studies have observed the presence of both Peak 1 and 2 with $\mathrm{Cu} / \mathrm{SSZ}-13$ and $\mathrm{H} /$ SSZ-13 catalysts [2-5]. Some of these studies assigned the high temperature peak to $\mathrm{NH}_{3}$ strongly bound to Brønsted acid sites [2, 4, 5]. Lezcano-Gonzalez et al. attributed the intermediate peak to $\mathrm{NH}_{3}$ adsorbed over $\mathrm{Cu}^{2+}$ sites [2]. On the other hand, Clemens et al. studied a larger number of copper loadings and observed that both Peaks 1 and 2 increased with $\mathrm{Cu}$ content. On this basis they assigned both these peaks to different unspecified types of $\mathrm{Cu}$ sites. Ma et al. attributed this peak to a combination of both Brønsted and Lewis acid sites [4]. This shows that there has not been a consensus on assignment of the TPD peaks. One reason for this is that studies looking at the trend with copper loading did not study many different copper loadings in the low range (below $40 \%$ IE), where the change between preferential filling of $6 \mathrm{MRs}$ and $8 \mathrm{MRs}$ occurs [6]. Moreover, there are, to our knowledge, no studies in literature which show a correlation between $\mathrm{NH}_{3}$ desorption peaks and site location in the zeolite structure. We therefore chose to focus on low copper loadings in this study, with six samples below $40 \%$ IE. To aid assignment, the $\mathrm{NH}_{3}$-TPD profiles were deconvoluted by fitting with three Gaussian curves, as shown in Fig. 3b. Similar adsorption experiments were carried out at $175^{\circ} \mathrm{C}$, to be able to exclude interference of Peak 3 with the interpretation (Fig. S1 in the Supplementary Materials). It is commonly accepted that the loosely bound fraction does not bind at this higher temperature, so that only two desorption peaks are seen, as in Fig. S1. The peaks in Fig. S1 were also deconvoluted, see Fig. S2. Looking at the coloured areas in both Fig. $3 b$ and Fig. $\mathrm{S} 2$, it is clear that the trends followed by the three peaks are not exactly the same. These differing trends may yield interesting information, as seen earlier for $\mathrm{H}_{2}$-TPR. This will be further discussed in Sect. 3.5. 


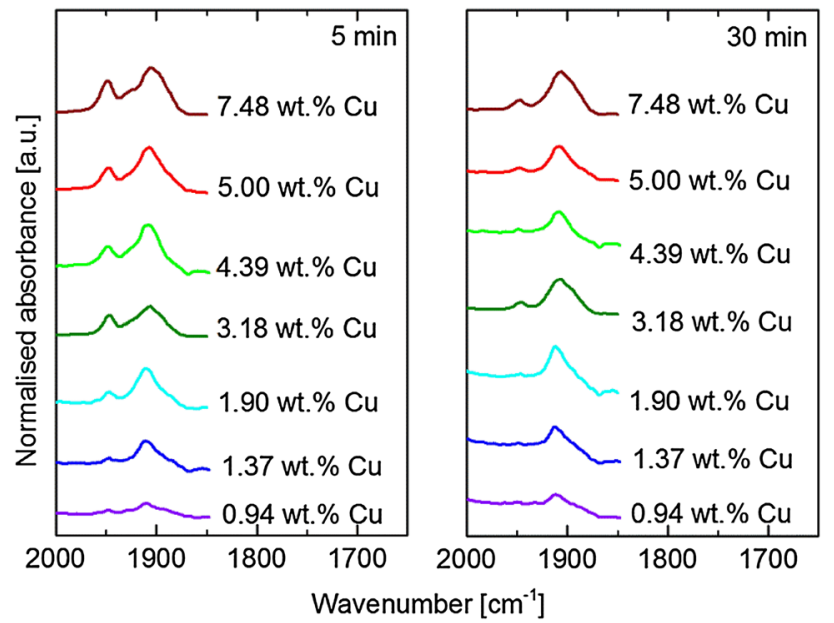

Fig. 4 NO-DRIFT spectra after 5 min (left panel) and $30 \mathrm{~min}$ (right panel) $\mathrm{NO}$ adsorption on $\mathrm{Cu} / \mathrm{SSZ}-13$ catalysts $(\mathrm{Si} / \mathrm{Al}=3.7)$. Flow rate $50 \mathrm{~mL} / \mathrm{min}, 500 \mathrm{ppm} \mathrm{NO}, 30^{\circ} \mathrm{C}$

\subsection{NO-DRIFTS}

More information about the different copper sites in the zeolite can be obtained from in-situ infrared spectroscopy of NO adsorption, since NO binds to both $\mathrm{Cu}^{2+}$ and $\mathrm{Cu}^{+}$. Therefore NO-DRIFTS measurements were carried out on the samples with different copper loadings. Note that the samples were pretreated in $\mathrm{O}_{2}$ at $500^{\circ} \mathrm{C}$, so that the copper sites are more likely to be present as $\mathrm{Cu}^{2+}$ than $\mathrm{Cu}^{+}$[15]. The results are shown in Fig. 4 and will be discussed for an adsorption time of 5 min (left panel of Fig. 4), as the increased DRIFT absorbances obtained after longer times make it difficult to distinguish some of the bands (right panel of Fig. 4). Note that we observed no bands in the region $1728-1810 \mathrm{~cm}^{-1}$, indicating that no $\mathrm{Cu}^{+}$species were present in our conditions $[6,16]$. Two main bands appear at wavenumbers of 1904-1911 and $1947-1949 \mathrm{~cm}^{-1}$, as well as a smaller shoulder at approximately $1930 \mathrm{~cm}^{-1}$. The absorbances in Fig. 4 are normalised with respect to the peak height at $\sim 1907 \mathrm{~cm}^{-1}$ for each sample, which makes it possible to compare the relative heights of the two bands. Kwak et al. and Zhang et al. assigned the two bands (1904 and $1948 \mathrm{~cm}^{-1}$ ) to NO binding to $\mathrm{Cu}^{2+}$ sites in the different cationic locations (6MR and 8MR units) $[6,17]$. Thus, like the $\mathrm{H}_{2}$-TPR results, NO-DRIFTS provides some evidence for the existence of $\mathrm{Cu}^{2+}$ sites in two different locations in dry conditions. In Sect. 3.5, we discuss the possibility of assigning the $\mathrm{NH}_{3}$-TPD peaks Peak 1 and Peak 2 to ammonia desorbed from sites in these two locations.

\subsection{Assigning $\mathrm{NH}_{3}$-TPD and NO-DRIFTS Peaks}

The number of copper sites in each location was obtained from integration of the deconvoluted $\mathrm{H}_{2}$-TPR profiles and is show in Fig. 5, in function of the copper loading (Fig. 5a). Similarly, the number of ammonia molecules stored was obtained from the peak areas and plotted in Fig. 5b. As discussed in Sect. 3.2, Fig. 5b shows that the sites in the 6MR units (Site 1) are populated first, at copper loadings below $1.7 \mathrm{wt} \%$. Between 1.7 and $4.3 \mathrm{wt} \%$, the large cages (Site 2) are also being filled, and then at higher loadings, the rate of filling of Site 2 increases and that of Site 1 levels off/ decreases. Note that the decrease is only seen for the last
Fig. 5 Synthesis of results in function of copper loading. a Amount of copper from $\mathrm{H}_{2}$-TPR peak area. $\mathbf{b}$ Amount of stored $\mathrm{NH}_{3}$ from $\mathrm{NH}_{3}$-TPD peak areas. c $\mathrm{NH}_{3}$-TPD and NO-DRIFTS ratio of $\mathrm{NH}_{3}$ stored on Site 1 versus Site 2

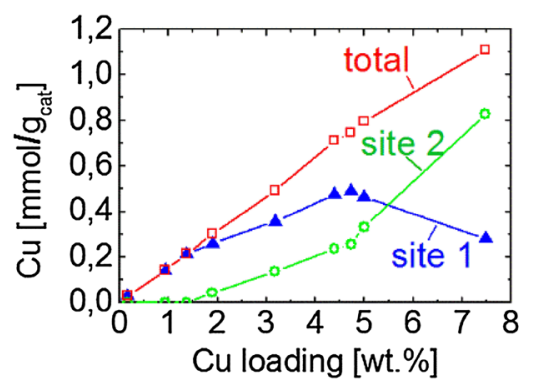

a

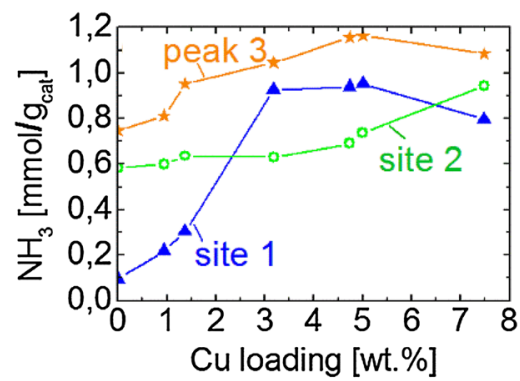

b

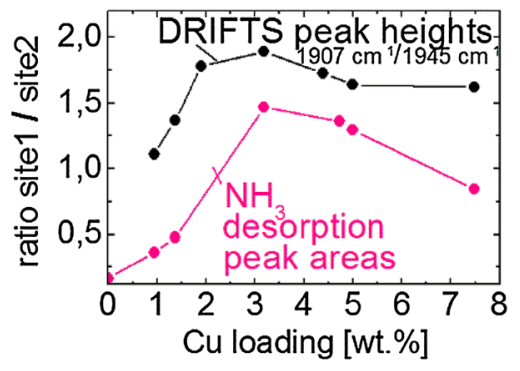

c 
point $(7.48 \mathrm{wt} \% \mathrm{Cu})$. This strongly depends on the choice of deconvolution parameters. As previously mentioned, the TPR profile for this last copper loading is somewhat different from the others, with evidence for at least one additional type of $\mathrm{Cu}$ species, which makes deconvolution more complex. In the deconvoluted results presented in Fig. 5, two sites were used for all samples, which could explain the deviation for the highest copper loading.

Figure 5b shows that Peak 1 and Peak 2 of the ammonia-TPD (adsorption at $70{ }^{\circ} \mathrm{C}$ ) follow very similar trends, respectively, to copper Sites 1 and 2: Peak 1 increases initially, and when it starts to level off $(3.2 \mathrm{wt} \% \mathrm{Cu})$, Peak 2 begins to increase. On the basis of this similarity, we propose that the intermediate $\left(238-319^{\circ} \mathrm{C}\right)$ and high temperature $\left(463-512^{\circ} \mathrm{C}\right)$ peaks observed during $\mathrm{NH}_{3}$-TPD can be assigned to desorption from sites in the $6 \mathrm{MR}$ and $8 \mathrm{MR}$ units, respectively. In the initial sample (H/SSZ-13), both locations are filled with Brønsted acid sites only. According to this interpretation, as the copper loading increases up to $3.2 \mathrm{wt} \% \mathrm{Cu}$, the Brønsted sites in the 6MRs are replaced with copper ions. Above this copper loading, the Brønsted sites in the 8MRs are preferentially replaced instead. Note that the highest copper loading in this study corresponds to an ion exchange level of $73 \%$, so that even for this last point, there is certainly a contribution of Brønsted sites to the high temperature desorption peak. It can also not be excluded that the Brønsted acid sites in the 6MRs have not all been replaced when the $\mathrm{Cu}$ ions start preferring to populate the $8 \mathrm{MRs}$, or that $\mathrm{Cu}^{+}$populates some sites instead of $\mathrm{Cu}^{2+}[2,3]$.

The TPD peaks obtained after $\mathrm{NH}_{3}$ adsorption at $175^{\circ} \mathrm{C}$ were also deconvoluted, as shown in the Supplementary Material (Fig. S2). Fig. S3 shows that the trend followed by the deconvoluted peaks as a function of copper loading is quite similar to that obtained for the $\mathrm{NH}_{3}$ adsorption at $70^{\circ} \mathrm{C}$, discussed in the previous paragraph. This further supports our interpretation that the intermediate (IT) and high temperature (HT) peaks observed during $\mathrm{NH}_{3}$-TPD can be assigned to desorption from sites in the 6MR and 8MR units, respectively. Note, however, that there is necessarily some uncertainty associated to the fits of the TPDs. Different fits are in fact possible, so that the high temperature peak increases immediately, instead of being stable at first, as in the fits shown in Fig. 5 and Fig. S3. It should also be noted that the TPR results show that $\mathrm{Cu}$ in $8 \mathrm{MRs}$ increases already quite early (below $3 \% \mathrm{Cu}$ ), so it cannot be excluded that there is some early $\mathrm{NH}_{3}$ adsorption in $8 \mathrm{MRs}$ too. It is therefore important to combine several observations in the interpretation, and ammonia TPD using different $\mathrm{Si}$ / $\mathrm{Al}$ ratios are therefore examined, which will be discussed in a later section. Moreover, even without deconvolution, it is clear from looking at the peak heights, that the intermediate temperature peak undergoes a much larger change than the high temperature peak. For example, $(5 \%$ $\mathrm{Cu}) /(0 \% \mathrm{Cu})$ equals 4 for the IT peak and 2.6 for the HT peak, in the adsorption experiment at $175^{\circ} \mathrm{C}$. Assigning the IT peak to 6MRs and HT peak to 8MRs is therefore in line with TPR results which show that there is a much larger (about double) amount of $\mathrm{Cu}$ in 6MRs compared to $8 \mathrm{MRs}$ at $5 \% \mathrm{Cu}$.

In Sect. 3.4 we discussed the possibility of assigning DRIFTS bands $\sim 1945$ and $\sim 1907 \mathrm{~cm}^{-1}$ to copper sites in the 6MRs and 8MRs. While it is difficult to make any comparison based on absolute DRIFTS absorbances, a ratio of peak heights (Peak 1/Peak 2) is easily compared, see Fig. 5c. A ratio of $\mathrm{NH}_{3}$ stored in locations 1 and 2 is also shown for comparison in Fig. 5b. Both ratios increase up to a maximum at $3.2 \mathrm{wt} \% \mathrm{Cu}$, and decrease thereafter. Note that for the last point the S1/S2 ratio from DRIFT does not decrease and the behaviour of this point differs depending on the time chosen for the analysis. As previously discussed, the highest $\mathrm{Cu}$ loading is affected by the presence of new, probably oxidic copper species, and we believe this contributes to the slightly different trend for the last point. Nevertheless, the overall similarity in the ratio $\mathrm{S} 1 / \mathrm{S} 2$ obtained from both DRIFT and $\mathrm{NH}_{3}$ storage, which is clearly seen in Fig. 5c, further supports our proposal that the TPD peaks at intermediate and high temperature can be assigned to ammonia storage in 6MR and $8 \mathrm{MR}$ units, respectively. Furthermore, on the basis of this observation, we propose that DRIFTS bands $\sim 1945$ and $\sim 1907 \mathrm{~cm}^{-1}$ be attributed to NO binding to $\mathrm{Cu}^{2+}$ sites in $8 \mathrm{MR}$ and $6 \mathrm{MR}$ units, respectively.

In order to further support the assignment of ammonia-TPD peaks to sites in 6MRs and 8MRs, we performed $\mathrm{H}_{2}$-TPR and $\mathrm{NH}_{3}$-TPD on three $\mathrm{Cu} / \mathrm{SSZ}-13$ samples with different $\mathrm{Si} / \mathrm{Al}$ ratios. The results are shown in Figs. 6 and

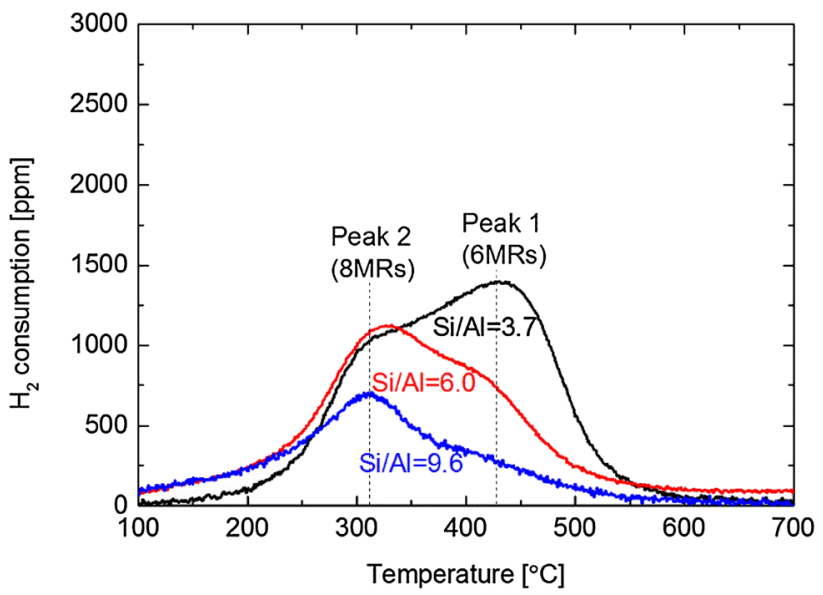

Fig. $6 \mathrm{H}_{2}$-TPR of $\mathrm{Cu} / \mathrm{SSZ}-13$ catalysts $(60 \mathrm{mg}$ catalyst, flow rate $20 \mathrm{~mL} / \mathrm{min}, 3000 \mathrm{ppm} \mathrm{H}_{2}$, heating rate $10^{\circ} \mathrm{C} / \mathrm{min}$ ) 


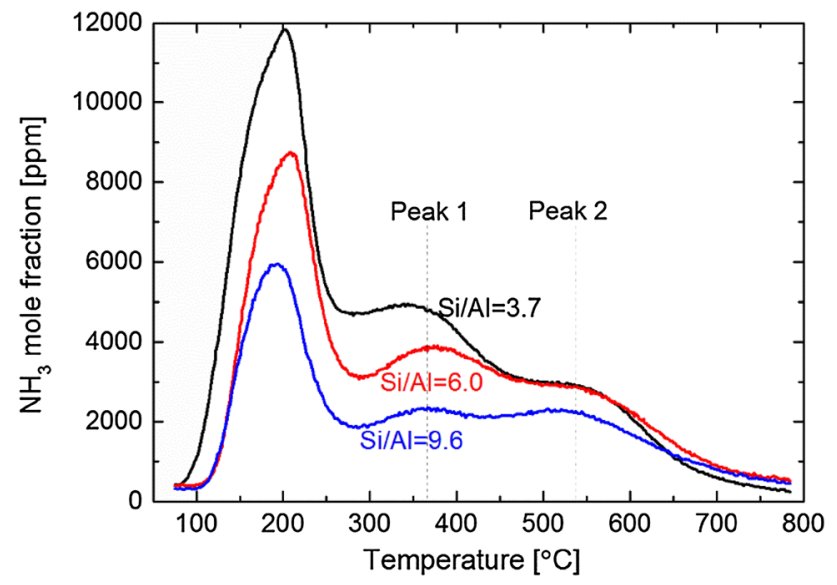

Fig. $7 \mathrm{NH}_{3}$-TPD profiles of $\mathrm{Cu} / \mathrm{SSZ}-13$ catalysts after $\mathrm{NH}_{3}$ adsorption and $\mathrm{Ar}$ purge over $\mathrm{Cu} / \mathrm{SSZ}-13$ at $70^{\circ} \mathrm{C}$. Adsorption time: $5 \mathrm{~h}$, purge time: $1 \mathrm{~h}$. Heating rate: $10^{\circ} \mathrm{C} / \mathrm{min}$, flow rate $20 \mathrm{~mL} / \mathrm{min}$, $2000 \mathrm{ppm} \mathrm{NH}$. Catalyst mass: $60 \mathrm{mg}$

7 , respectively. It can be seen from the areas under the reduction profiles in Fig. 6 that the samples have different copper loadings, as also determined by ICP (results shown in Table 2). However, what is interesting for our purpose is the ratio between Peak $1\left(>430^{\circ} \mathrm{C}\right)$ and 2 $\left(\sim 300^{\circ} \mathrm{C}\right)$. These peaks are known to correspond to $\mathrm{Cu}$ in $6 \mathrm{MR}$ and $8 \mathrm{MR}$ windows, respectively. It is clear from the figure, that the ratio $(\mathrm{Cu}$ in $6 \mathrm{MRs}) /(\mathrm{Cu}$ in $8 \mathrm{MRs})$ increases with a decrease in Si/Al. Examination of Fig. 7 shows that the ratio $\left(\mathrm{NH}_{3}\right.$-TPD Peak 1$) /\left(\mathrm{NH}_{3}\right.$-TPD Peak 2) is likewise increasing with decreasing $\mathrm{Si} / \mathrm{Al}$. Like our observations based on copper loadings and DRIFTS peaks (in the preceding paragraphs), this finding therefore indicates that $\mathrm{NH}_{3}$-TPD Peak 1 could be assigned to sites in the 6MRs, and $\mathrm{NH}_{3}$-TPD Peak 2 to sites in the 8MRs. The results from zeolites with different $\mathrm{Si} / \mathrm{Al}$ ratios are thus consistent with the results obtained with zeolites of different $\mathrm{Cu}$ loadings, and with DRIFTS.

\subsection{Ammonia Oxidation Catalytic Activity}

Ammonia oxidation experiments were performed to test the catalytic activity of the $\mathrm{Cu} / \mathrm{SSZ}-13$ catalysts with different $\mathrm{Cu}$ loadings. Results from the kinetic regime (i.e. conversions below 12\%) are shown in the Arrhenius plot in Fig. 8. The results were used to determine the activation energies in Table 4. Overall, the activation energy for ammonia oxidation increases with copper loading, except for the sample with the highest loading, $7.48 \mathrm{wt} \%$ $\mathrm{Cu}$. Closer examination of Fig. 8 shows that the straight lines fall roughly into two categories, $\mathrm{Ea} \leq 50 \mathrm{~kJ} / \mathrm{mol}$, and $\mathrm{Ea}>50 \mathrm{~kJ} / \mathrm{mol}$. This observation is in line with the results of $\mathrm{Gao}$ et al. who identified two distinct kinetic regimes of ammonia oxidation, with $\sim 130 \mathrm{~kJ} / \mathrm{mol}$

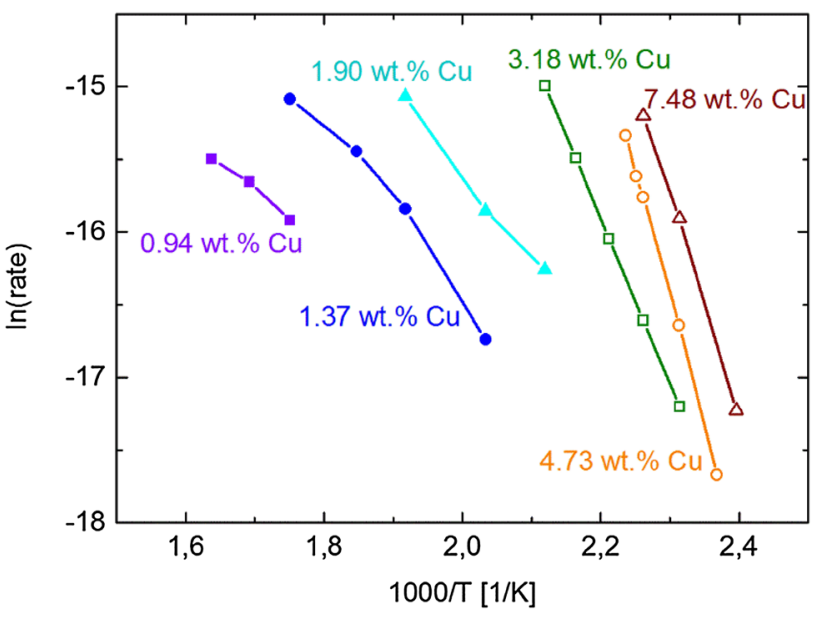

Fig. $8 \mathrm{NH}_{3}$-oxidation activity data in the kinetic regime $\left(\mathrm{NH}_{3}\right.$ conversions up to $12 \%$ ). Total flow rate $100 \mathrm{~mL} / \mathrm{min}, 1200 \mathrm{ppm} \mathrm{NH}_{3}, 8 \%$ $\mathrm{O}_{2}$. Catalyst mass: $35 \mathrm{mg}$

between 175 and $250{ }^{\circ} \mathrm{C}$ and $\sim 60 \mathrm{~kJ} / \mathrm{mol}$ between 250 and $30{ }^{\circ} \mathrm{C}$ [18]. Gao et al. found that $\mathrm{Cu} / \mathrm{SSZ}-13$ catalysts with different copper loadings all adopted both of these kinetic regimes. Our results indicate that copper loadings up to $1.90 \mathrm{wt} \%$ adopt a lower activation energy $(\leq 50 \mathrm{~kJ} /$ $\mathrm{mol}$ ), at temperatures roughly below $200^{\circ} \mathrm{C}$. Higher copper loadings, above $1.90 \mathrm{wt} \%$ adopt an activation energy above $50 \mathrm{~kJ} / \mathrm{mol}$ at temperatures above $200^{\circ} \mathrm{C}$. On the basis of our results, we propose that the reason for the appearance of the two kinetic regimes is connected to the copper loading, and thus to the copper site location (6MR vs. $8 \mathrm{MR}$ ). It is thus worth noting that the $8 \mathrm{MRs}$ start to be significantly populated between 1.90 and $3.18 \mathrm{wt} \%$ $\mathrm{Cu}$, which is also where the change from one kinetic regime to another occurs in our results. These results are in line with our kinetic model for Cu/SSZ-13 [19], where a low activation energy, based on Arrhenius data, was found for $\mathrm{Cu}$ in $6 \mathrm{MR}$, while a significantly higher value was used for ammonia oxidation occurring on $\mathrm{Cu}$ in $8 \mathrm{MR}$. This interpretation, resulted in us being able to explain the unusual ammonia oxidation behaviour, where the rate first increases with temperature, thereafter levels off and finally increases more rapidly.

Table 4 Ammonia oxidation activation energies determined from data in Fig. 8

\begin{tabular}{lc}
\hline Cu wt $\%$ & Ea $(\mathrm{kJ} / \mathrm{mol})$ \\
\hline 7.48 & 126 \\
4.73 & 147 \\
3.18 & 95 \\
1.90 & 50 \\
1.37 & 49 \\
0.94 & 31 \\
\hline
\end{tabular}




\section{Conclusions}

Copper and Brønsted sites in $\mathrm{Cu} / \mathrm{SSZ}-13$ are located in $8 \mathrm{MRs}$ and $6 \mathrm{MR}$ units. We propose that ammonia stored on both types of site may desorb at $238-319^{\circ} \mathrm{C}$ when located in the $6 \mathrm{MRs}$ and at $463-512{ }^{\circ} \mathrm{C}$ when inside the $8 \mathrm{MRs}$. Moreover, we propose that copper sites in these locations give rise to DRIFTS bands at $\sim 1907$ and $\sim 1945 \mathrm{~cm}^{-1}$, respectively.

Acknowledgements This work was supported by Cummins Inc. and the Swedish Research Council [Grant number 642-2014-5733].

Open Access This article is distributed under the terms of the Creative Commons Attribution 4.0 International License (http:// creativecommons.org/licenses/by/4.0/), which permits unrestricted use, distribution, and reproduction in any medium, provided you give appropriate credit to the original author(s) and the source, provide a link to the Creative Commons license, and indicate if changes were made.

\section{References}

1. Toops TJ, Pihl JA, Partridge WP (2014) Fe-zeolite functionality, durability, and deactivation mechanisms in the selective catalytic reduction (SCR) of NOx with ammonia. In: Nova I, Tronconi E (eds) Urea-SCR technology for deNOx after treatment of diesel exhausts. Springer, New York, pp 97-121

2. Lezcano-Gonzalez I, Deka U, Arstad B, Van Yperen-De Deyne A, Hemelsoet K, Waroquier M, Van Speybroeck V, Weckhuysen B, Beale A (2014) Determining the storage, availability and reactivity of $\mathrm{NH} 3$ within $\mathrm{Cu}$-Chabazite-based ammonia selective catalytic reduction systems. Phys Chem Chem Phys 16:1639-1650

3. Clemens AKS, Shishkin A, Carlsson P-A, Skoglundh M, Martínez-Casado FJ, Matej Z, Balmes O, Härelind H (2015) Reaction-driven ion exchange of copper into zeolite SSZ-13. Acs Catal 5:6209-6218

4. Ma L, Cheng Y, Cavataio G, McCabe RW, Fu L, Li J (2014) In situ DRIFTS and temperature-programmed technology study on NH3-SCR of NOx over Cu-SSZ-13 and Cu-SAPO-34 catalysts. Appl Catal B 156-157:428-437

5. Wang D, Gao F, Peden CH, Li J, Kamasamudram K, Epling WS (2014) Selective catalytic reduction of NOx with NH3 over a CuSSZ-13 catalyst prepared by a solid-state ion-exchange method. ChemCatChem 6:1579-1583

6. Kwak JH, Zhu H, Lee JH, Peden CHF, Szanyi J (2012) Two different cationic positions in Cu-SSZ-13? Chem Commun 48:4758-4760
7. Su W, Li Z, Peng Y, Li J (2015) Correlation of the changes in the framework and active $\mathrm{Cu}$ sites for typical $\mathrm{Cu} / \mathrm{CHA}$ zeolites (SSZ-13 and SAPO-34) during hydrothermal aging. Phys Chem Chem Phys 17:29142-29149

8. Leistner K, Mihai O, Wijayanti K, Kumar A, Kamasamudram $\mathrm{K}$, Currier NW, Yezerets A, Olsson L (2015) Comparison of $\mathrm{Cu} /$ BEA, $\mathrm{Cu} / \mathrm{SSZ}-13$ and $\mathrm{Cu} / \mathrm{SAPO}-34$ for ammonia-SCR reactions. Catal Today 258:49-55

9. Leistner K, Brüsewitz F, Wijayanti K, Kumar A, Kamasamudram K, Olsson L (2017) Impact of copper loading on NH3selective catalytic reduction, oxidation reactions and $\mathrm{N}_{2} \mathrm{O}$ formation over $\mathrm{Cu} / \mathrm{SAPO}-34$. Energies 10:489

10. Praliaud H, Mikhailenko S, Chajar Z, Primet M (1998) Surface and bulk properties of $\mathrm{Cu}-\mathrm{ZSM}-5$ and $\mathrm{Cu} / \mathrm{Al}_{2} \mathrm{O}_{3}$ solids during redox treatments. Correlation with the selective reduction of nitric oxide by hydrocarbons. Appl Catal B 16:359-374

11. Schoonheydt RA (1993) Transition metal ions in zeolites: siting and energetics of $\mathrm{Cu}^{2+}$. Catal Rev 35:129-168

12. Wilken N, Wijayanti K, Kamasamudram K, Currier NW, Vedaiyan R, Yezerets A, Olsson L (2012) Mechanistic investigation of hydrothermal aging of $\mathrm{Cu}$-Beta for ammonia SCR. Appl Catal B 111-112:58-66

13. Wilken N, Nedyalkova R, Kamasamudram K, Li J, Currier N, Vedaiyan R, Yezerets A, Olsson L (2013) Investigation of the effect of accelerated hydrothermal aging on the $\mathrm{Cu}$ sites in a $\mathrm{Cu}-$ BEA catalyst for $\mathrm{NH}_{3}$-SCR applications. Top Catal 56:317-322

14. Park J-H, Park HJ, Baik JH, Nam I-S, Shin C-H, Lee J-H, Cho BK, Oh SH (2006) Hydrothermal stability of CuZSM5 catalyst in reducing $\mathrm{NO}$ by $\mathrm{NH}_{3}$ for the urea selective catalytic reduction process. J Catal 240:47-57

15. Szanyi J, Kwak JH, Zhu H, Peden CH (2013) Characterization of $\mathrm{Cu}-\mathrm{SSZ}-13 \mathrm{NH}_{3}$ SCR catalysts: an in situ FTIR study. Phys Chem Chem Phys 15:2368-2380

16. Giordanino F, Vennestrøm PN, Lundegaard LF, Stappen FN, Mossin S, Beato P, Bordiga S, Lamberti C (2013) Characterization of $\mathrm{Cu}$-exchanged SSZ-13: a comparative FTIR, UV-Vis, and EPR study with $\mathrm{Cu}-\mathrm{ZSM}-5$ and $\mathrm{Cu}-\beta$ with similar $\mathrm{Si} / \mathrm{Al}$ and $\mathrm{Cu} /$ Al ratios. Dalton Trans 42:12741-12761

17. Zhang R, McEwen J-S, Kollár Mr, Gao F, Wang Y, Szanyi Jn, Peden CH (2014) NO chemisorption on Cu/SSZ-13: a comparative study from infrared spectroscopy and DFT calculations. Acs Catal 4:4093-4105

18. Gao F, Walter ED, Karp EM, Luo J, Tonkyn RG, Kwak JH, Szanyi J, Peden CHF (2013) Structure-activity relationships in NH3-SCR over Cu-SSZ-13 as probed by reaction kinetics and EPR studies. J Catal 300:20-29

19. Olsson L, Wijayanti K, Leistner K, Kumar A, Joshi S, Kamasamudram K, Currier NW, Yezerets A (2015) A multisite kinetic model for NH3-SCR over Cu/SSZ-13. Appl Catal B 174-175:212 